\title{
The Determinant of FDI Inflows in OIC Countries
}

\author{
Tania Megasari \\ Universitas Gadjah Mada, Indonesia \\ Corresponding email: taniamegasari02@gmail.com
}

Samsubar Saleh

Universitas Gadjah Mada, Indonesia, ssamsubar@yahoo.com

Article History

Received: July 29 2 th 2020 Revised: January 15 ${ }^{\text {th }}, 2021$ Accepted: January $21^{\text {st }}, 2021$

\begin{abstract}
This study aims to analyze the determinants of foreign direct investments (FDI) incountry members of the Organization of Islamic Cooperation (OIC) from 2005 to 2018. The determinant variables of FDIs are corruption, political stability, and macroeconomic variables, such as inflation, exchange rates, economic growth, and trade openness. The analysis used in the study is the fixed effect model (FEM) of the OIC data panel. The results showed that economic growth and trade openness significantly influenced foreign direct investment (FDI), while the effects of corruption, political stability, inflation, and the exchange rate had none. The results imply that governments need to increase the degree of economic openness by reducing trade barriers (exports and imports), both in the form of rates and non-rates.
\end{abstract}

Keywords: corruption, political stability, macroeconomic variables, FDI, OIC JEL Classification : F21; F50; O50

Type of paper: Research Paper

@ IJIEF 2021 published by Universitas Muhammadiyah Yogyakarta, Indonesia All rights reserved

DOI:

https://doi.org/10.18196/ijief.v4i1.9473
Web:

https://journal.umy.ac.id/index.php/ijief/article/view/9473

Citation:

Megasari, T \& Saleh, S. (2021) The Determinant of FDI Inflows in OIC Countries. International Journal of Islamic Economics and Finance (IJIEF), 4(1), 31-50. DOI: https://doi.org/10.18196/ijief.v4i1.9473. 


\section{Introduction}

OIC is an organization consisting of 57 Islamic countries as a forum for cooperation in various fields, not only in politics but also in the economic field and many more. The level of development in member countries of the OIC is very diverse. They are separated into groups that are considered low, low to middle, upper-middle, and high. According to the World Bank (2018), only $12.29 \%$ of OIC member countries are included in high-income countries. Therefore, most OIC countries' economies are still lagging behind non-OIC member countries. One of the ways to increase economic growth is through investments. According to Harrord (1939) and Dhomar (1946) theory, advancing economic growth can be done through investments because it would raise a country's productivity. Foreign and local investors could make investments.

Foreign Direct Investment (FDI) is an investment from a foreign country, which means external financing. However, developing countries' external funding to achieve sustainable goals tends to be large and is generally unfulfilled due to investor speculation. Based on a survey from Global Investment Competitiveness (2017), one of the essential factors in investor decision making is political stability, security, and the bureaucratic environment. To create political stability is to eradicate corruption. With the eradication of corruption, political stability will positively impact macroeconomic stability. Variables that affect FDI include inflation, exchange rates, economic growth, and trade openness. So that foreign investors are interested in investing

In the political economy, some researches have been conducted using nonOIC countries. Ghairabeh has done the first research in 2015 that examines the determinants of FDI in Bahrain - followed by (Boateng, Hua, Nisar, \& Wu, 2015) that examines FDI determinants in Norway. Canare (2017) examined the effects of corruption on FDI. Third, (Karim, Karim, \& Nasharuddin, 2018) reviewed the influence of corruption and FDI in 5 ASEAN member countries. Fourth, (Asamoah, Adjasi, \& Alhassan, 2016) examined macroeconomic uncertainty, FDI, and institutional quality in Sub-Saharan African countries. These studies examine only one country or countries in a development level group. Therefore, the researcher was interested in OIC countries due to their varying developments and income leveling from low to high. It will determine which FDI has the most decisive influence in each country based on their national income, allowing for grand policies that positively impact the countries. 


\subsection{Objective}

This research has two objectives, to analyze the relationship between corruption, political stability, macroeconomic variables, and FDI in OIC countries and discuss what policies should be made by OIC countries' members. FDI is influenced by various factors, including corruption, political stability, and macroeconomic variables. Macroeconomic variables that affect FDI include inflation, exchange rates, economic growth, and trade openness. Research on the factors that influence FDI is interesting to discuss because each country has its policies and will affect the flow of FDI in the country. The paper comprises five sections. The next section provides the literature review. The methodology is discussed in the third section, followed by; and the results and analysis in the fourth section. The final section presents the conclusion and recommendations.

\section{Literature Review}

\subsection{Background Theory}

Foreign Direct Investment (FDI) is an international capital flow when companies from one country open their branch into other countries. FDI is not only a capital; investors are also in control of the company, so that subsidiary companies have the same organizational structure as the parent company. There are two reasons for firms to go international, to serve foreign markets, and to reduce production cost. FDI has two types, namely vertical FDI and horizontal FDI. Vertical FDI is an investment where the business activities are different from their parent company because it has a different geographic location where the production cost is cheaper. Hence, it becomes profitable to split the production chain. Horizontal FDI is an investment where the business activities are similar to the parent company. It happens because it's cheaper to duplicate the same products in different countries (Krugman, Obstfeld, \& Melitz, 2012).

FDI has positive and negative effects on the host country. The positive results are, 1) increasing output product, 2) raising wages, 3) lowering unemployment rate, 4) raising exports, 5) raising tax revenues, 6) giving technical and managerial skills and acquiring new technologies, 8) decreasing the power of domestic monopoly. While the adverse impact is 1) bringing losses to the commodity terms of trade, 2) deepening the pricing transfer, 3 ) deepening the domestic investment, 5) growing instability in the balance of payment and exchange rate, 6) removing the control of domestic policy, 7) 
raising the number of unemployment, 8) creating local monopolies, 9) local education and skills are underpaid (Appleyard, Field, \& Cobb, 2014).

Moosa (2004) claims five theories describe the foreign direct investment: 1) The differential return rate that the current capital from one country to another with a low return rate would move to a faster return rate. FDI decided on two considerations: marginal return and marginal cost. 2) The diversification fluctuations mean the investment decision in a project is not only calculated by the rate of return but also by the magnitude of the potential risks. In this theory, there are three levels of investors. The first is risk-averse. At this level, the investor has the nature of avoiding risk to choose a low-risk group project. However, sometimes it has a low-risk rate. The second is an average risk. At the average level, the investor has a proportionate nature of viewing risk by investing in a moderate risk project. The last is the risk-taker. At this rate, the investor has the bold nature of taking significant risks because it has a high return rate. 3) The output and market size suggest that its small size FDI flows into a country depending on the size of the output from multinational corporations on the country or the size of the market size of the country's goals is based on GDP. 4) The Currency Areas Hypothesis is a theory that states that a corporation in a country that has a substantial currency value compared with others will generally invest in another country. 5) The Product Life Cycle Hypothesis is a theory which states that the first released product in the land of origin is an innovation, but over time it will be standardized. FDI has emerged due to corporate reactions to overseas expansion, which is at risk of losing the market as its products continue to grow.

Corruption is a behavior that deviates from formal duties and public roles (Nye, 1967). This deviation occurs because of personal interests in obtaining a certain amount of money or status that violates the rules or abuses authority. According to (Othman, Shafie, \& Hamid, 2014), there are three main reasons why a person commits corruption, power, opportunity, and low moral impurity. When a country has a high level of corruption, the business environment will be affected, causing foreign investors to be more likely to lose assets or have fewer profit margins. Hence, foreign investors, in choosing their destination country, would consider the extent of the corruption of the target country. Foreign investors would select countries with adequate capabilities to protect assets and profit margins.

Political stability, according to Ake (1975), is an orderly flow of changes in political rules. If the flow of political exchange is more organized, politics will be stable. Political stability and security are absolute conditions for economic development. Political policies, events, or conditions in the less stable and 
poor host countries will affect the business environment, so foreign investors tend to lose assets or have fewer profit margins (Howell \& Chaddick, 1994)

The exchange rate is the unit price of a currency in another currency (Samuelson, 2001). The exchange rate presents exchange rates from one currency to another, allowing for various international transactions such as trade between countries, tourism, global investment, and other international transactions. Goldbreg \& Kolstad (1995) states that when a country's currency depreciates, the price of goods and services from foreign currencies becomes cheaper. So, it would attract foreign investors to invest in the country because it would get more profit.

Inflation is a monetary phenomenon that occurs because of a decline in the value of the economic calculation unit of a product. According to Mishkin (2008), inflation is a continuous increase in the price of both goods and services in general, so that it affects various groups from individuals to the government. Foreign investors will find it challenging to set fees and prices from products when they are high. When high inflation rates persist over a long period, foreign investors will tend to reduce the power invested in the country (Asamoah et al., 2016). A high inflation rate will reduce the inflow of FDI into the host country.

Economic growth is an indicator used to show economic activity changes within a certain period. Economic Growth is generally calculated using the Gross Domestic Product (GDP). The concept of measuring economic growth has shortcomings because it only shows economic value, so it cannot measure the community's welfare as a whole. According to the (Harrord, 1939) and (Dhomar, 1946) theory, when economic growth becomes higher and it will attract to invest. A country that has a high level of trade openness may mean it can be interpreted that the government has an international economic activity that can attract foreign investors. So, if trade openness is high, that means the country is in good condition to receive foreign investment.

\subsection{Previous Studies}

Until now, the topic of FDI's determinants still attracts the attention of researchers, as can be seen from the large number of studies examining a specific country (Boeateng et al., 2015; Ghairabeh, 2015) and in a group of countries (Gangi \& Abdulrazak. 2012; Asamoah et al., 2016; Canare. 2017; Kumari \& Sharma. 2017; Karim et al., 2018)

Gangi \& Abdulrazak (2012) examined the impact of government indicators on FDI in Africa between 1966 and 2010. The results obtained are that three of the six indicators have a significant effect. The indicators were voice and 
accountability, government effectiveness, and law rule. These results indicate that countries in Africa need to improve their government conditions, to improve the investment climate and FDI.

Boetang et al. (2015) examined the determinants of Norway's FDI between 1986 and 2009. The results obtained are that economic growth, exchange rates, and trade openness have significant positive effects on FDI. In contrast, money supply, inflation, unemployment, and interest rates have significant adverse effects on FDI. So, it can be concluded that to promote a competitive advantage in the country of origin, the government needs to pay attention to macroeconomic policies.

Between 1980 until 2013 in Bahrain, general government consumption expenditure, inflation rate, and economic stability were represented by annual interest rates, labor force, trade openness, public education, and population. It has a statistically significant relationship with FDI inflows (Ghairabeh, 2015). Therefore, these factors are considered the main aspects of Bahrain's FDI entry.

Asamoah et al. (2016) examined the macroeconomic variables, FDI, and institutional quality in Sub-Saharan African countries between 1996 and 2011. The results obtained were that the quality of institutions, economic growth, and exchange rates significantly affected FDI. So that it can be concluded that Sub-Saharan countries need methods to improve the quality of institutions, one of which is by planning government policies that can attract foreign investors to invest.

Canare (2017) discusses the effects of corruption on 46 countries in the Asia Pacific. This study indicates that corruption has a significant impact on FDI in high-income countries. However, in low and middle-low-income countries, it can be understood that foreign investors see other factors such as the quality of the regulator.

Kumari \& Sharma (2017) researched the determinants of FDI in twenty developing countries in Asia from 1990 to 2012 with seven variables. The research found that four variables, namely market size, trade openness, interest rate, and human capital yield, significantly affect FDI. As policymakers, it is necessary to make more friendly foreign investors' regulations and further improve human capital.

Karim et al. (2018) examined corruption and its effect on FDI in ASEAN-5 countries. The results obtained were that corruption and economic growth significantly affected FDI. Therefore, governments need to cooperate and continue to improve the integrity and credibility of their administration and 
Megasari \& Saleh | The Determinant of FDI Inflows in OIC Countries

transactions. Besides, maintaining sustainable economic growth is also a significant factor in attracting more FDI inflows in the future.

\section{Methodology}

\subsection{Data}

The study used a dataset of selected OIC member states. Data were collected from the World Governance Indicator, World Bank, and the Statistical, Economic, and Social Research and Training Centre for Islamic Countries (SESRIC). The data used is annual data covering 2005 to 2018. Period range selection is limited by adequate data availability for all variables.

Based on the consideration of data availability, this study uses a sample of 47 countries from 57 OIC member countries or represents $82.45 \%$ of all OIC countries. The unavailability of data caused the explanation of the ten countries not included in the study.

\subsection{Model Development}

In this study, the author used a panel data model because it combines crosssection data and time-series data. The panel data model has advantages over cross-section and time-series data in using all the evidence obtained, which are allow us to test more complicated than pure cross-section or time-series data (Baltagi, 2005). This study aims to determine FDI and use independent variables from macroeconomic factors such as economic growth, inflation, exchange rate, trade openness, and institutional factors such as corruption and political stability. This relationship can model as:

$$
\text { FDI }=\mathrm{f}(\mathrm{CC}, \mathrm{PSAV}, \mathrm{INF}, \mathrm{GDPgr}, \mathrm{TO}, \mathrm{ER})
$$

FDI here represents foreign direct investment inflow in OIC countries; CC represents corruption control. This index is an indicator that captures perceptions of the extent to which public power is exercised for private gain, including minor and major forms of corruption by rulers and private interests. The control of the corruption index gives scores ranging from -2.5 to 2.5 for each country. A higher index value indicates that the level of corruption in a country is relatively low. On the other hand, if it is close to -2.5 , the level of corruption in that country is high. PSAV represents Political Stability and the Absence of Violence. The political stability index is when a government is 
elected, monitored, and replaced. The political stability index provides scores ranging from -2.5 to 2.5 for each country. A higher index value indicates that the level of political stability in a country is relatively stable; on the other hand, if it approaches -2.5 , the level of political conditions in that country is unstable.

INF is defined as Inflation. Inflation used in this study is a consumer price index that describes the percentage of annual change in the average consumer's cost of obtaining goods and services. GDPgr represents Gross Domestic Product Growth, and TO is defined as Trade Openness. The trade openness variable is obtained from the calculation between the number of exports and imports of goods and services, which are measured as part of GDP. So, when a country in higher exports and imports percentage of GDP, the chance of open trade is high. ER represents the exchange rate. The exchange rate used in this study is the official exchange rate (LCU per US\$, period average). In this study, the exchange rate converted into logarithmic to reduce the chance of heteroskedasticity

In this study, we used panel data of 47 OIC countries from 2005 to 2018 and used Fixed Effects within Group Model. This model approach reduces unobserved error by assuming each period's characteristics are the same. The errors can be classified into two classifications: time-variant error ( $v$ ) and idiosyncratic error $(\mu)$. Because the time-variant error value does not change for each individual, it can be eliminated by reducing the time-variant error by the time-variant error rate itself. The impact is that all variables and idiosyncratic errors are less than their mean. Besides, to increase efficiency in the model, a robust standard error is possibly used. (Woolridge, 2012).

The analytical model in this study can be formulated as follows:

$$
\mathrm{FDI}_{\mathrm{it}}=\beta_{0}+\beta_{1} \mathrm{cc}_{\mathrm{it}}+\beta_{2} P S A V_{i t}+\beta_{3} I N F_{i t}+\beta_{4} E R_{i t}+\beta_{5} G D P g r_{i t}+\beta_{6} T O_{i t}+\varepsilon_{i t}
$$

\section{Where:}

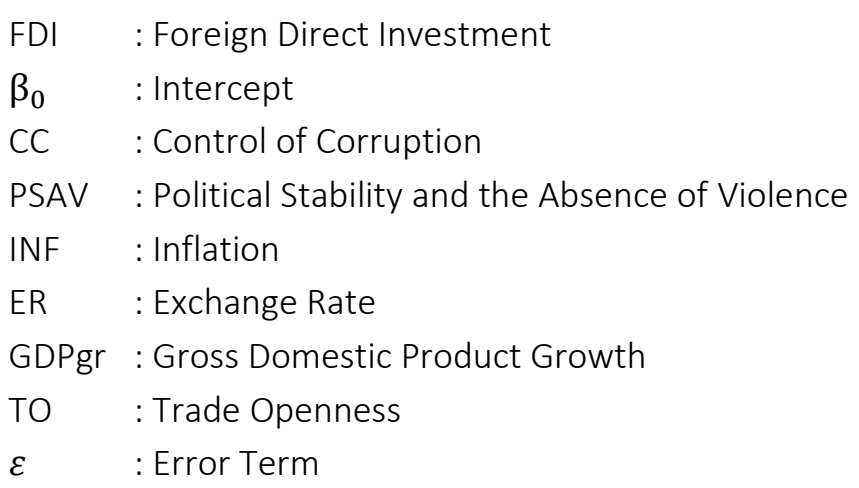




\subsection{Method}

This study uses panel data analysis techniques. Panel data analysis technique is a combination of cross-section data, which is symbolized by $\mathrm{N}$, and timeseries data, illustrated by $\mathrm{T}$ (Hsiao, 2007). Panel data analysis has advantages over several other analytical techniques, including panel data with more diverse sample data than cross data and time series so that degrees of freedom will be higher and thus produce more efficient econometric estimates. (Hsiao, 2007)

According to Hsiao (2007), there are three approaches in the static panel regression model, which is, 1) Common Effect Model (CEM). CEM is the most straightforward modeling technique for estimating the parameters. CEM is done by combining cross-section and time-series data without paying attention to the differences between the individual and the time. 2) Fixed Effect Model (FEM). In the regression panel, there is a possibility of unobserved error being present because there's a repeat of identity all the time. Therefore, the unobserved error must be eliminated to ensure that the model estimate capabilities are improved. In FEM, the unobserved error is assumed in time-invariant. 3) Random Effect Model (REM). This modeling technique takes that disorder variable maybe interrelates between time and between individuals. So, it does not correlate with the oft-examined definitional variable.

Classic assumption tests were made before regression testing the static data panel. There are three definitive assumption tests: multicollinearity test, heteroscedasticity test, and autocorrelation test. After that, three tests to choose the most precise model to manage the data panel, which is, 1) Chow test, is a test to determine whether FEM or CEM is best used in estimating static panel data, 2) Hausman test is a test to determine whether FEM or REM is best used to estimate static panel data, and 3) Lagrange Multiplier test determines whether REM or CEM is best used in evaluating static panel data.

This study uses FEM with robust regression. Its means that the test was conducted on models with heteroscedasticity and autocorrelation problems (Wooldridge, 2002). The usage of FEM will minimize the error and resolve heteroscedasticity and autocorrelation issues in the model. 


\section{Results and Analysis}

\subsection{Results}

Table 4.1. Descriptive Statistics of Determinant FDI

\begin{tabular}{llllll}
\hline Variable & Obs & Mean & Std. Dev & Min & Max \\
\hline FDI & 658 & 4.231056 & 5.118182 & -4.852285 & 39.4562 \\
CC & 658 & -0.5872222 & 0.6127743 & -1.638287 & 1.567186 \\
PSAV & 658 & -0.6382845 & 0.9193312 & -2.82731 & 1.387627 \\
INF & 658 & 5.462609 & 6.361138 & -10.06749 & 63.29 \\
ER & 658 & 1.685307 & 1.234287 & -0.5705249 & 4.153417 \\
GDPgr & 658 & 4.680932 & 4.207697 & -20.59877 & 34.46621 \\
TO & 658 & 79.43852 & 34.9056 & 19.1008 & 203.8546 \\
\hline
\end{tabular}

* Foreign Direct Investment Net Inflows (FDI) as the dependent variable

Source: primary data processed (2010)

The descriptive statistical analysis aims to describe the data used by compiling and arranging data based on specific sizes without intending to conclude. The statistical measures commonly used for descriptive statistical analysis are mean, maximum, minimum, and standard deviation (Table 4.1.)

The FDI variable has a maximum value of 39.4562 , a minimum value of 4.852285, and a mean value of 4.231056. In table 4.1, it can be seen that the standard deviation of FDI has a value that is greater than the mean, so it can be concluded that there is a data imbalance. The highest FDI value was 39.4562, and the lowest was -4.852285 percent of its contribution to GDP. The highest was in the country of Mozambique in 2013 and the lowest in Chad in 2014. The lowest score experienced by the government of Chad illustrates that there was considerable disinvestment that year. The score shows the imbalance of foreign investment in OIC Member Countries. The mean value of 4.231056 shows that the FDI level in OIC countries has a positive growth of $4.23 \%$.

The Control of Corruption variable has a maximum value of 1.567186 achieved by the Qatar state in 2009, while the lowest control of corruption value is the Afghan state in 2008, which reached -1.638287. The mean value is 0.5872222 , and the standard deviation is 0.6127743 . It can be concluded that the $\mathrm{OIC}$ member countries are still weak to eradicate existing corruption. The situation also happens to the political stability of OIC member countries. In the range of 2005 to 2018, the mean value of political stability was 0.6382845 , and the standard deviation value was 0.9193312 . The maximum value of political stability was 1.387627 in Brunei Darussalam in 2009, and the lowest minimum value of -2.82731 in the country of Iraq in 2006. The leading 
cause of the low level of political stability in OIC member countries is that there are still rampant civil conflicts between OIC member states.

The inflation variable has a mean value that is smaller than the standard deviation of 5.462609, while the standard deviation is 6.361138 , so that it can be seen that there is an imbalance in OIC member countries. The minimum value of -10.06749 in Iraq in 2007, the maximum value of 63.29 in the government of Sudan in 2018. With a massive ratio of minimum and maximum values, it can be seen that there is quite a difference in the inflation rate between OIC member countries, especially in developing countries. or less developing countries.

Meanwhile, the exchange rate variable has a maximum value of 4.153417, a minimum value of -0.5705249 , a standard deviation of 1.234287 , and a mean of 1.685307. The exchange rate variable has a standard deviation value smaller than the mean value, so it can be concluded that there is no data imbalance. The highest exchange rate, namely 4.153417, occurred in Indonesia in 2018, while the lowest exchange rate was -0.5705249 in Kuwait in 2008.

The GDP growth variable has a maximum value of 34.46621, a minimum value of -20.59877 . The GDP growth variable has a standard deviation value smaller than the mean value, which is 4.207697 , while the mean value is 4.680932 , so it can be concluded that there is no data inequality. The highest GDP growth value was 34.46621 achieved by Azerbaijan in 2006, and the lowest was 20.59877 in Sierra Leone in 2015. The mean value is 4.680932, which means that OIC member countries have a positive economic growth rate of $4.68 \%$

The exchange trade openness (TO) variable has a maximum value of 203.8546 in Malaysia in 2005. A minimum value of 19,1008 occurred in Sudan in 2015, a standard deviation of 34,90564 and a mean of 79.43852 . The trade openness variable has a standard deviation value smaller than the mean value, so it can be concluded that there is no data imbalance.

Table 4.2. The Results of Chow Test, Hausman Test, and Lagrange Multiplier Test

\begin{tabular}{|c|c|c|c|c|}
\hline Model* & Model & Prob. & Result & Decision \\
\hline \multirow{4}{*}{$\begin{array}{l}\text { Predictors: Control of Corruption (CC), Political } \\
\text { Stability and Absence of Violence (PSAV), Inflation } \\
\text { (INF), Growth GDP Per Capita (GDPgr), Exchange } \\
\text { Rate (ER), Trade Openness (TO) }\end{array}$} & $\begin{array}{l}\text { Chow } \\
\text { (CEM: FEM) }\end{array}$ & 0,000 & $\begin{array}{l}\text { Fixed Effect } \\
\text { Model }\end{array}$ & \\
\hline & $\begin{array}{l}\text { Hausman } \\
\text { (REM: FEM) }\end{array}$ & 0.0037 & $\begin{array}{l}\text { Fixed Effect } \\
\text { Model }\end{array}$ & $\begin{array}{l}\text { Fixed } \\
\text { Effect }\end{array}$ \\
\hline & Lagrange & & Random & Model \\
\hline & $\begin{array}{l}\text { Multiplier } \\
\text { (CEM: REM) }\end{array}$ & 0.0000 & $\begin{array}{l}\text { Effect } \\
\text { Model }\end{array}$ & \\
\hline
\end{tabular}

Source: Secondary data processed (2020) 
Based on table 4.2, it can be decided that the fixed effect model (FEM) is better than the expected effect (CEM) and the random effect (REM) model. In the Chow test and the Hausman test, the fixed effect model was chosen because the probility value is smaller than the significance value $\alpha=0.05$. In the Langrange Multipler test, random effect model (REM) is better than the expected effect (CEM) because the probility value is smaller than the significance value $\alpha=0.05$ The conclusion is that the fixed effect model is the best model for this study, among other models because in the Chow test and the Hausman test has a same results.

The multicollinearity test detects whether the correlation relationship exists between independent variables. Table 4.3. shows that the overall value of the correlation coefficient is less than 0.8 , where if the value of the correlation coefficient is less than 0.8 , then there exists no multicollinearity between independent variables.

The Heteroscedasticity test detects whether there is a constant error variance. The Wald test did the test in this study. Table 4.4. shows that the value (Prob> chi2) is 0.0000 , which means the value (Prob> chi2) is smaller than the significance value $\alpha=0.05$. The number means that there is $a$ heteroscedasticity problem in the model.

The autocorrelation test detects whether there exist residual correlations between observation units. Table 4.4 shows that the value (Prob> F) is smaller than $\alpha=0.05$, which means that the autocorrelation test results have autocorrelation problems.

Table 4.3. Multicollinearity Test

\begin{tabular}{llllllll}
\hline Variable & FDI & CC & PSAV & INF & ER & GDP GR & TO \\
\hline FDI & 1.000 & & & & & & \\
CC & -0.0186 & 1.0000 & & & & & \\
PSAV & 0.1268 & 0.6645 & 1.0000 & & & & \\
INF & 0.0922 & -0.2797 & -0.3279 & 1.0000 & & & \\
ER & -0.0154 & -0.5753 & -0.3193 & 0.0511 & 1.0000 & & \\
GDP GR & 0.2221 & -0.0497 & -0.0269 & 0.0890 & 0.0162 & 1.0000 & \\
TO & 0.3152 & 0.4265 & 0.3639 & -0.1614 & -0.4086 & 0.0440 & 1.0000 \\
\hline \multicolumn{7}{c}{ Source: Secondary data processed (2020) }
\end{tabular}

Table 4.4. Result of Heteroscedasticity \& Autocorrelation Test

\begin{tabular}{cc}
\hline Heteroscedasticity Test & Autocorrelation Test \\
\hline Prob>chi2 & Prob $>$ F \\
0.0000 & 0.0000 \\
\hline
\end{tabular}

Source: Secondary data processed (2020) 
Table 4.5 The Empirical Results

\begin{tabular}{ll}
\hline Variable & Coefficient \\
\hline CC & 1.480789 \\
& $(0.118)$ \\
\hline PSAV & -0.0588752 \\
& $(0.918)$ \\
\hline INF & 0.0378151 \\
& $(0.290)$ \\
\hline ER & 0.6398378 \\
& $(0.538)$ \\
\hline GDP gr & $0.1877152^{*}$ \\
& $(0.008)$ \\
\hline TO & $0.0972672^{*}$ \\
& $(0.001)$ \\
\hline C & -4.831105 \\
\hline$R^{2}$ & 0.1793 \\
\hline Adjusted- $R^{2}$ & 0.1169 \\
\hline Prob $>F$ & 0.0001
\end{tabular}

* Significant

Source: Secondary data processed (2020)

The fixed-effect model in this paper encountered heteroscedasticity and autocorrelation problems. This problem can be solved by the robust standard error method. The full standard error can correct standard errors in models with heteroscedasticity and autocorrelation problems (Wooldridge, 2002).

Table 4.5 shows the value smaller than 0.05 , which meant that economic growth and trade openness significantly affect foreign direct investment. Meanwhile, the other variables, such as corruption, political stability, inflation, and exchange rate, has no significant effect on foreign direct investment because of their significance value more significant than 0.05 , and the panel data regression estimation showing the influence of the independent variables on the dependent variables. Based on Table 4.6, the Rsquares value is 0.1169 . The value of 0.1169 indicates that the independent variable can explain $11.69 \%$ of the dependent variable's variation.

\subsection{Analysis}

First, the corruption variable shows a significance value of $0.118(p>0.05)$, which means that it has no significant effect on foreign direct investment. This result is impressive because OIC countries' majorities contain low and middlelow countries, whereas corruption is worse among developing countries. The result can be explained by how foreign investors see other institutional 
variables. The results of this study are consistent with the results of research conducted by Gangi \& Abdulrazak (2012), Jadhav (2012), Udenze (2014), and Canare (2017).

Second, political stability shows a significance value of $0.918(p>0.05)$, which means that it has no significant effect on foreign direct investment. The regression coefficient value of political stability (PSAV) is -0.0588752 . The result happens because there are differences in each investor in assessing the political risk. Each foreign investor also has its preferences for investing in a country, one of which is the natural resources that are profitable for the country. Each country has its characteristics that attract investors. Investors themselves have several ways to reduce the effects of political risk by using political risk insurance so that political stability does not affect investors to invest in a country. The results of this study are consistent with research conducted by Jaspersen (2000), Hausman and Fernandez (2000), Gangi \& Abdulrazak (2012), Jadhav (2012), Kurul and Yalta (2017), which state that political stability does not affect foreign direct investment (FDI).

Third, inflation shows a significance value of 0.290 ( $p>0.05$ ), which means that it has no significant effect on foreign direct investment. Inflation does not have a significant impact because, for investors, a price increase is still more substantial than an increase in the entire production that must be issued. Therefore, investors still have a profit. Thus, inflation does not affect. These results are consistent with the results of research conducted by Udenze (2014), Gharaibeh (2015), and Alshamsi, Hussin \& Azam (2015).

Fourth, the exchange rate shows a significance value of $0.538(p>0.05)$, which means that it has no significant effect on foreign direct investment. The results are consistent with the theory of "The Currency Areas hypothesis," which is a theory which states that if a country whose exchange rate strengthened compared with an investment destination will provide investment in the country in hopes of getting a higher return rate. However, the exchange rate did not significantly affect the foreign direct investment (FDI) of this result following the research of Gharaibeh (2015) and Xaypanya, Rangkakulnuwat, \& Paweenawat (2015) because investors generally see the condition of infrastructure and economic growth. The amount of value is not too calculated by foreign investors, and foreign direct investment (FDI) is longterm. Simultaneously, the exchange rate tends to fluctuate in a short time (seasonal).

Fifth, economic growth shows a significance value of $0.008(p>0.05)$, which significantly affects foreign direct investment. The regression coefficient value of exchange rate variables (GDP gr) is 0.1877152 , which means that when the economic growth increases by one scale, foreign direct investment (FDI) will 
increase by 0.1877152 . The results of this study are following the hypothesis, which states that economic growth has a positive and significant effect on foreign direct investment (FDI). These results are consistent with the results of research by Jadhav (2012), Asideu (2013), Tintin (2013), Alshamsi, Hussin, \& Azam (2015), Asamoah (2016), Ulah and Khan (2016), and Karim et al. (2018). Increased economic growth in a country shows an increase in market size (market size). A larger market will increase commodity demand. The increase in sales in a country's market reflects that the government can already compete. Investors who enter the market will benefit, so foreign investors are interested in investing in that country.

Sixth, trade openness shows a significance value of $0.001(p>0.05)$, which significantly affects foreign direct investment. The regression coefficient value of Trade Openness (TO) is 0.0972672, which means that when the trade openness increases by one scale, foreign direct investment (FDI) will increase by 0.0972672 . These results are following research by Jadhav (2012), Asideu (2013), Tintin (2013), Asamoah (2016), Ullah and Khan (2017). Trade openness is created from the presence of an open economy. The open economy itself is an economy that can interact freely with other economies in various parts of the world (Mankiw, 2006). The impact of trade openness will open up economic paths between countries so that it will open up opportunities for foreign investors to enter into a nation; therefore, foreign investors prefer to invest in countries that have a high level of trade openness.

\section{Conclusion and Recommendation}

\subsection{Conclusion}

This paper aims to determine the determinants of Foreign Direct Investment (FDI) in OIC countries from 2005 to 2018. These determinants include corruption, political stability, inflation, exchange rates, economic growth, and trade openness. The results of this paper are the variables of corruption, political stability, inflation, and the exchange rate does not affect foreign direct investment (FDI). In contrast, the variables of economic growth and trade openness affect foreign direct investment (FDI). Although these study results are the same as previous studies, some are not the same. It is hoped that in the future, research can find answers to why the results are inconsistent.

Like other studies, this study also has limitations. There are still some determinants of FDI that are not included, such as interest rate, unemployment rate, the rule of law, government effectiveness, and 
Megasari \& Saleh $\mid$ The Determinant of FDI Inflows in OIC Countries

regulatory quality in this model. It is hoped that further researchers can add these variables and increase the period.

\subsection{Recommendation}

The recommendations based on the study results can be summarized as follows. First, governments need to issue a policy so that foreign investors are interested in investing their capital. One way is to increase economic growth to encourage the flow of FDI. Second, governments need to increase the degree of economic openness by reducing trade barriers (exports and imports), both in the form of rates and non-rates. 


\section{References}

Alshamsi, K., Hussin, M., \& Azam, M. (2015). The impact of inflation and. Investment management \& financial innovations GDP per capita on foreign direct investment: the case of United Arab Emirates., 132-141. Retrieved May 4, 2020, from https://businessperspectives.org/images/pdf/applications/publishin g/templates/article/assets/6875/imfi_en_2015_03cont_Alshamsi.pd $f$

Aggarwal, R. (2003). Allocation of initial public offerings and flipping activity. Journal of Financial Economics, 68(1), 111-135. Retrieved May 1, 2020,

from https://www.sciencedirect.com/science/article/abs/pii/S0304405X0 2002507

Ake, C. (1975). A Definition of Political Stability. Comparative Politic, 7(2), 271283. Retrieved May 2, 2020, from https://www.jstor.org/stable/421552?seq=1

Alshamsi, K. H., Hussin, M. R., \& Azam, M. (2017). The impact of inflation and GDP per capita on foreign direct investment: the case of United Arab Emirates. Investment management and financial innovations, 12, 132-141. Retrieved May 1, 2020, from https://www.semanticscholar.org/paper/The-impact-of-inflationand-GDP-per-capita-on-the-AlshamsiHussin/b1aec1927b9fOd2ccbca212ae13d4da91d858c16

Anggarwal, R., Prabhala, N. R., \& Puri, M. (2002). Institutional Allocation in Initial Public Offerings: Empirical Evidence. The Journal of Finance, 1421-1442. Retrieved May 2, 2020, from https://www.nber.org/papers/w9070

Appleyard, D., Field, A., \& Cobb, S. (2014). International economics. New York: The McGraw-Hill series economics.

Asamoah, M. E., Adjasi, C. K., \& Alhassan, A. L. (2016). Macroeconomic uncertainty, foreign direct investment and institutional quality: Evidence from Sub-Saharan Africa. Economic Systems, 612-621. Retrieved May 3, 2020, from https://www.sciencedirect.com/science/article/abs/pii/S093936251 6300759\#: :text=The\%20study\%20examines\%20the\%20moderating ,investment\%20in\%20Sub\%2DSaharan\%20Africa.\&text=The\%20resu Its\%20show\%20that\%20macroeconomic,increases\%20the\%20flow\% 20of\%20FDI.

Asiedu, E. (2013). Foreign direct investment, natural resources and institutions. International Growth Centre. Retrieved May 2, 2020, from https://www.theigc.org/wp-content/uploads/2014/09/Asiedu2013-Working-Paper.pdf 
Baltagi, B. H. (2005). Econometric Analysis of Panel Data. London: John Wiley \& Sons Ltd.

Boateng, A., Hua, X., Nisar, S., \& Wu, J. (2015). Examining the determinants of inward FDI: Evidence from Norway. Economic Modelling, 47, 118-127. Retrieved May 1, 2020, from https://www.sciencedirect.com/science/article/abs/pii/S026499931 5000358

Canare, T. (2017). The effect of corruption on foreign direct investment inflows : Evidence from a panel of Asia-Pacific countries. The Changing Face of Corruption in the Asia Pacific:Curent Perspectives and Future Challenges, 35-55. Retrieved May 3, 2020, from https://www.sciencedirect.com/science/article/pii/B978008101109 6000034

Case, K. E., Fair, R. C., \& Oster, S. E. (2007). Principles of economics. London: Pearson.

Dhomar, E. D. (1946). Capital expansion, rate of growth, and employment. Econometrica, 14(2), 137-147. Retrieved May 3, 2020, from https://www.jstor.org/stable/1905364

Gangi, Y. A., \& Abdulrazak, R. S. (2012). The impact of governance on FDI flows to African countries. World Journal of Entrepreneurship, Management and Sustainable Development, 8(2/3), 162-169. Retrieved May 1, 2020, from https://www.emerald.com/insight/content/doi/10.1108/204259612 $11247761 /$ full/html

Ghairabeh, A. M. (2015). The determinants of foreign direct investment empirical evidence from Bahrain. International Journal of Business and Social Science, 6(8). Retrieved May 1, 2020, from http://ijbssnet.com/journals/Vol_6_No_8_August_2015/11.pdf

Global Investment Competitiveness. (2017). Retrieved from http://documents.worldbank.org/curated/en/169531510741671962 /Global-investmentcompetitiveness-report-2017-2018-foreigninvestor perspectives-and-policy-implications.

Goldbreg, L., \& Kolstad, C. (1995). Foreign direct investment, exchange rate variability and demand uncertainty. 36(4), 855-873. Retrieved April 30, 2020, from https://www.jstor.org/stable/2527262?seq=1

Harrord, R. (1939). An Essay in Dynamic Theory. The Economic Journal, 49(193), 14-33. Retrieved May 1, 2020, from http://piketty.pse.ens.fr/files/Harrod1939.pdf

Hausman, R., \& Fernández-Arias, E. (2000). Foreign direct investment: good cholesterol? IDB Working Paper. Retrieved May 4, 2020, from https://papers.ssrn.com/sol3/papers.cfm?abstract_id=1817215 
Howell, L., \& Chaddick, B. (1994). Models of political risk for foreign investment and trade: an assessment of three approaches. The Columbia Journal of World Business, 29(3), 70-91. Retrieved May 3, 2020,

from https://www.sciencedirect.com/science/article/abs/pii/0022542894 900485

Hsiao, C. (2007). Panel data analysis-advantages and challenges. Mathematics Subject Classification. Retrieved May 2, 2020, from https://link.springer.com/article/10.1007/s11749-007-0046-x

Jadhav, P. (2012). Determinants of foreign direct investment in BRICS economics: Analysis of economic, institutional and political factor. Procedia - Social and Behavioral Sciences, 37, 5-14. Retrieved April 29, 2020, from https://www.sciencedirect.com/science/article/pii/S1877042812007 495

Jaspersen, F., Aylward, A., \& Knox, A. (2000). Risk and private investment: africa compared with other developing areas. Investment and Risk in Africa, 71-95. Retrieved April 29, 2020, from Investment and Risk in Africa

Kahneman , D., \& Tversky, A. (1979). Prospect theory: An Analysis of decision under risk. Econometrica, 47(2), 263-292. Retrieved May 1, 2020, from https://www.jstor.org/stable/1914185?seq=1

Karim, B. A., Karim, Z. A., \& Nasharuddin, M. (2018). Corruption and Foreign Direct Investment ( FDI) in ASEAN-5 : A panel evidence. Economics and Finance in Indonesia, 64(2), 145-156. Retrieved May 3, 2020, from http://efi.ui.ac.id/index.php/efi/article/view/594

Krugman, P. R., Obstfeld, M., \& Melitz, M. J. (2012). International economics: theory \& policy, Global Edition. London: The Pearson.

Kumari, R., \& Sharma , A. (2017). Determinants of foreign direct investment in developing countries: a panel data study. International Journal of Emerging Markets, 12(4), 658-682. Retrieved May 3, 2020, from https://www.emerald.com/insight/content/doi/10.1108/IJoEM-102014-0169/full/html

Kurul, Z., \& Yalta, A. (2017). Relationship between institutional factors and FDI flows in developing countries: New evidence from dynamic panel estimation. Economies, 5(2), 1-10. Retrieved May 5, 2020, from https://www.mdpi.com/2227-7099/5/2/17

Mankiw, N. (2008). Principle of Macroeconomics. Boston: Cengange Learning.

Mishkin, F. (2008). The economics of money banking and financial markets. London: Pearson.

Moosa, I. (2004). International Finance. Melbourne: La Trobe Unversity. 
Megasari \& Saleh | The Determinant of FDI Inflows in OIC Countries

Nye, J. (1967). Corruption and political development: A cost benefit analysis. The American Political Science Review,, 61(2), 417-427. Retrieved April 30, 2020, from https://www.jstor.org/stable/1953254?seq=1

Othman, Z., Shafie, R., \& Hamid, F. (2014). Corruption - Why do they do it? Procedia - Social and Behavioral Sciences, 248-257. Retrieved May 3, 2020, from https://www.sciencedirect.com/science/article/pii/S1877042814058 947

Samuelson, P., \& Nordhaus, W. (2001). Macroeconomics. New York: McGrawHill Higher Education.

Tintin, C. (2013). The determinants of foreign direct investment inflows in the Central and Eastern European Countries: The importance of institutions. Communist and Post-Communist Studies, 46(2), 287-298. Retrieved April 30, 2020, from https://www.sciencedirect.com/science/article/abs/pii/S0967067X1 3000159

Udenze, O. (2014). The effect of corruption on foreign direct investments in developing countries. The Park Place Economist, 87-95. Retrieved May 4, 2020, from https://digitalcommons.iwu.edu/cgi/viewcontent.cgi?article=1416\& context=parkplace\&httpsredir=1\&referer=

Ullah, I., \& Khan, M. (2017). Institutional quality and foreign direct investment inflows: evidence from Asian countries. Journal of Economic Studies, 44, 1030-1050. Retrieved May 1, 2020, from https://www.emerald.com/insight/content/doi/10.1108/JES-102016-0215/full/html

Wooldridge, J. (2002). Econometric analysis of cross section and panel data. Massachusetts: The MIT Press.

World Bank. (2018). World Bank List of Economies. Retrieved July 20, 2019, from http://data.worldbank.org/indicator

Xaypanya , P., Rangkakulnuwat , P., \& Paweenawat , S. (2015). The determinants of foreign direct investment in ASEAN. International Journal of Social Economics, 239-250. Retrieved May 5, 2020, from https://www.emerald.com/insight/content/doi/10.1108/IJSE-102013-0238/full/html 